\title{
Efektivitas Biaya Terapi Cairan Kristaloid dan Koloid pada Pasien Anak Demam Berdarah di Rumah Sakit PKU Muhammadiyah Bantul
}

\author{
Chotijatun Nasriyah, Baiq A.A. Munawwarah, Dyah A. Perwitasari \\ Fakultas Farmasi, Universitas Ahmad Dahlan, Yogyakarta, Indonesia
}

\begin{abstract}
Abstrak
Demam berdarah dengue (DBD) merupakan penyakit yang disebabkan oleh virus dengue yang ditularkan melalui gigitan nyamuk Aedes aegypti. Kunci keberhasilan terapi pada penyakit demam berdarah adalah pemberian cairan termasuk jenis dan jumlahnya. Dari aspek biaya terapi, cairan koloid diketahui lebih mahal dibandingkan cairan kristaloid. Tujuan dari penelitian ini adalah untuk mengetahui efektivitas biaya terapi cairan kristaloid dan koloid pada pasien anak demam berdarah periode Januari 2018 sampai Juni 2018 di Rumah Sakit PKU Muhammadiyah Bantul. Penelitian ini menggunakan desain penelitian eksperimental single blind randomized clinical trial. Sejumlah 48 pasien anak yang memenuhi syarat inklusi dibagi menjadi dua kelompok yaitu kelompok intervensi $(n=24)$ yang mendapatkan terapi cairan koloid berupa inisial cairan gelafusal dan kelompok kontrol $(n=24)$ yang mendapatkan terapi cairan kristaloid tunggal berupa ringer laktat. Data efektivitas (lama rawat inap) dan total biaya medis dianalisis menggunakan independent t-test dan rumus average cost-effectiveness ratio (ACER). Terdapat perbedaan yang signifikan lama rawat inap antara kelompok cairan kristaloid dibandingkan kelompok cairan koloid $(p<0,05)$. Hasil penelitian menunjukkan perbandingan nilai ACER yaitu nilai ACER kelompok koloid (Rp28.560/efektivitas) lebih rendah dari nilai ACER kelompok kristaloid (Rp62.328/ efektivitas). Kesimpulan dari penelitian ini adalah terapi cairan koloid lebih cost-effective dibandingkan cairan kristaloid.
\end{abstract}

Kata kunci: Efektivitas biaya, koloid, kristaloid

\section{Cost-Effectiveness of Crystalloid and Colloid Therapy in Children with Dengue Fever in PKU Muhammadiyah Hospital, Bantul}

\begin{abstract}
Dengue hemorrhagic fever (DHF) is a disease caused by the dengue virus which is transmitted through the bite of the Aedes aegypti mosquito. The key to the success of therapy in dengue fever is the administration of fluids including types and quantities. Based on its cost, colloid fluid therapy are known to be more expensive than crystalloid fluid therapy. The purpose of this study was to determine the costeffectiveness of crystalloid and colloid fluid therapy in dengue fever patients in the period of JanuaryJune 2018 at PKU Muhammadiyah Hospital Bantul. This study employed an experimental single blind randomized clinical trial design. A total of 48 pediatric patients who met the inclusion requirements were divided into two groups, namely the intervention group $(n=24)$ who received colloid fluid therapy in the form of initial gelafusal fluid and control group $(n=24)$ who received single crystalloid fluid therapy in the form of ringer lactate. Effectiveness data (length of stay) and total medical costs were analyzed using independent t-test and the average cost-effectiveness ratio (ACER) formula. There was a significant difference in length of stay between groups of crystalloid fluid compared to the group of colloid fluid $(p<0.05)$. The ACER values of the colloid group $(28,560$ IDR/effectiveness) was lower than the crystalloid group (62,328 IDR/effectiveness). The conclusion of this study is that colloid fluid therapy group is more cost-effective than crystalloid fluid group.
\end{abstract}

Keywords: Colloid, cost-effectiveness, crystalloid

Korespondensi: Chotijatun Nasriyah, M.Farm., Apt., Fakultas Farmasi, Universitas Ahmad Dahlan, Yogyakarta, D.I. Yogyakarta 55164, Indonesia, email: 805.nasri@gmail.com

Naskah diterima: 22 Januari 2019, Diterima untuk diterbitkan: 13 Februari 2019, Diterbitkan: 1 Maret 2019 


\section{Pendahuluan}

Demam berdarah dengue (DBD) adalah penyakit yang disebabkan oleh 4 serotipe virus dengue (DENV). Penyakit ini menjadi permasalahan kesehatan masyarakat yang terjadi di negara berkembang maupun negara maju. ${ }^{1}$ Frekuensi demam berdarah telah meningkat dalam kurun waktu 40 tahun terakhir di sebagian besar negara Asia dan Amerika Latin, dan kini telah menjadi penyebab utama rawat inap serta kematian pada anak-anak. ${ }^{2}$ Indonesia sendiri masih ditemukan endemik disertai ledakan wabah demam berdarah yang muncul pada berbagai periode tertentu. Hasil pengamatan epidemiologis juga menunjukkan bahwa jumlah kejadian penyakit demam berdarah di Indonesia terus meningkat dari tahun ke tahun dengan penyebaran yang luas. ${ }^{3}$

Virus demam berdarah dengue mudah ditularkan dari nyamuk betina dewasa dan nyamuk yang terinfeksi menular sepanjang umurnya. ${ }^{4}$ Manifestasi klinis dari penyakit demam berdarah dengue ini meliputi demam tinggi secara mendadak, sakit kepala, nafsu makan berkurang, mialgia dan artralgia, ruam kulit yang muncul tiga hingga empat hari setelah awal timbulnya demam, nyeri retroorbital, fotofobia, limfadenopati, perdarahan ringan dan tes turniket positif. ${ }^{5}$ Manifestasi yang terkait dengan kebocoran plasma dan perdarahan berpotensi untuk menyebabkan syok hipovolemik. ${ }^{6}$

Manajemen klinis infeksi dengue berfokus pada perawatan suportif, dengan penekanan khusus pada manajemen cairan yang cermat. ${ }^{7}$ Kristaloid dan koloid merupakan dua jenis cairan yang digunakan untuk menggantikan kebocoran plasma. ${ }^{8}$ Tidak ada keuntungan yang jelas mengenai penggunaan dari koloid dibandingkan dengan kristaloid dalam hal hasil keseluruhan. Namun, koloid dapat menjadi pilihan yang lebih baik karena telah terbukti dapat mengembalikan indeks jantung dan mengurangi tingkat hematokrit lebih cepat dibandingkan dengan kristaloid pada pasien dengan syok yang tidak dapat diatasi, serta tekanan nadi kurang dari 10 mmHg. ${ }^{9}$ Di sisi lain, biaya terapi cairan koloid diketahui lebih mahal dibandingkan cairan kristaloid. ${ }^{10}$ Oleh sebab itu, peneliti tertarik untuk mengetahui perbandingan efektivitas biaya penggunaan terapi cairan kristaloid dan koloid pada pasien anak demam berdarah di Rumah Sakit PKU Muhammadiyah Bantul.

\section{Metode}

Penelitian ini telah mendapatkan persetujuan laik etik yang diperoleh dari Komisi Etik Penelitian Kesehatan RSUD Dr. Moewardi dengan nomor 63/II/HREC/2018 dan mendapat persetujuan wali pasien (informed consent). Penelitian dilakukan di bangsal anak Rumah Sakit PKU Muhammadiyah Bantul periode bulan Januari sampai dengan Juni tahun2018. Desain penelitian ini yaitu eksperimental single blind randomized clinical trial, yakni dengan melakukan uji klinis pada kelompok intervensi dan terdapat kelompok pembanding.

Sejumlah 48 pasien anak dengan diagnosis dengue fever (ICD-10:A90) atau dengue hemorrhagic fever (ICD-10:A91) yang telah memenuhi kriteria inklusi dibagi menjadi dua kelompok, yaitu kelompok intervensi $(n=24)$ yang mendapatkan terapi cairan koloid berupa inisial cairan gelafusal $10 \mathrm{ml} / \mathrm{kg}$ BB selama 15 menit kemudian dilanjutkan dengan cairan ringer laktat sesuai standar terapi di rumah sakit, dan kelompok kontrol $(n=24)$ yang mendapatkan terapi cairan kristaloid tunggal berupa ringer laktat. Kriteria inklusi pada penelitian ini yaitu pasien dengue fever dan dengue hemorrhagic fever baik perempuan dan laki-laki usia 1 bulan sampai 18 tahun yang bersedia menjadi responden penelitian dan telah mengisi lembar informed consent. Kriteria eksklusi penelitian ini adalah pasien yang mendapatkan terapi cairan sebelumnya dan dirujuk ke tingkat pelayanan kesehatan 
Tabel 1 Tabel Analisis Efektivitas Biaya

\begin{tabular}{lccc}
\hline \multicolumn{1}{c}{ Efektivitas-Biaya } & Biaya Lebih Rendah & Biaya Sama & Biaya Lebih Tinggi \\
\hline Efektivitas Lebih Rendah & A (Perlu perhitungan ICER) & B (Didominasi) & C (Didominasi) \\
Efektivitas Sama & D (Dominan) & E (Seimbang) & F (Didominasi) \\
Efektivitas Lebih Tinggi & G (Dominan) & H (Dominan) & I (Perlu perhitungan ICER) \\
\hline
\end{tabular}

Keterangan: ICER=Incremental cost-effectiveness ratio

yang lebih tinggi.

Pemberian jenis cairan dilakukan dengan berdasarkan randomisasi yang dilakukan selama penelitian, yaitu randomisasi blok. Parameter yang diukur pada penelitian ini yaitu lama rawat inap pasien dan total biaya medis berupa biaya administrasi, biaya rawat inap, biaya tindakan medis, biaya pelayanan medis, biaya obat dan biaya laboratorium. Data dianalisis dengan independent samples t-test dan rumus average cost-effectiveness ratio (ACER). Analisis efektivitas biaya juga menggunakan alat bantu seperti pada Tabel 1 .

\section{Hasil}

Total 48 pasien yang memenuhi kriteria inklusi dibagi menjadi 2 kelompok yaitu 24 pasien cairan ksritaloid (ringer laktat) dan 24 pasien cairan koloid (gelafusal). Karakteristik pasien dapat dilihat pada Tabel 2. Lama rawat inap dalam penelitian ini diukur dengan hitungan hari selama pasien mendapatkan perawatan di rumah sakit. Frekuensi lama rawat inap dapat dilihat pada Tabel 3. Pada penelitian ini juga dilakukan perhitungan persentase efektivitas terapi cairan terhadap lama rawat inap yang terdapat pada Tabel 4. Analisis rata-rata biaya total pada penelitian ini dihitung dari biaya administrasi, biaya rawat inap, biaya tindakan medis, biaya pelayanan medis, biaya obat dan biaya laboratorium yang terdapat pada Tabel 5. Analisis selanjutnya yang dilakukan yaitu menghitung rasio efektivitas biaya (ACER) antara kelompok cairan kristaloid dan cairan koloid. Nilai ACER memberikan gambaran bahwa rasio biaya pengobatan perpasien dibandingkan efektivitas pengobatan yang didapatkan menunjukkan keefektifan serta efisiensi pengobatan seperti yang ditunjukkan pada Tabel 6.

\section{Pembahasan}

Hasil pada Tabel 2 menunjukkan mayoritas subjek adalah pasien perempuan sejumlah 26 pasien $(54,2 \%)$, sedangkan pasien laki-laki sejumlah 22 pasien $(45,8 \%)$. Hasil tersebut

Tabel 2 Karakteristik Pasien Penelitian (n=24)

\begin{tabular}{|c|c|c|c|c|c|}
\hline Karakteristik & n (\%) & Mean \pm SD & $\begin{array}{c}\text { Cairan Kristaloid } \\
\text { n (\%) } \\
\end{array}$ & $\begin{array}{c}\text { Cairan Koloid } \\
\text { n (\%) }\end{array}$ & Nilai p \\
\hline \multicolumn{6}{|l|}{ Jenis Kelamin } \\
\hline $\begin{array}{l}\text { Laki-laki } \\
\text { Perempuan }\end{array}$ & $\begin{array}{l}22(45,8) \\
26(54,2)\end{array}$ & - & $\begin{array}{r}6(27,3) \\
18(69,2)\end{array}$ & $\begin{array}{l}16(72,7) \\
8(30,8)\end{array}$ & $0,564^{\mathrm{a}}$ \\
\hline \multicolumn{6}{|l|}{ Usia } \\
\hline $\begin{array}{l}<1 \text { tahun } \\
1-5 \text { tahun } \\
6-10 \text { tahun } \\
11-15 \text { tahun }\end{array}$ & $\begin{array}{c}1(2,0) \\
35(72,9) \\
10(20,8) \\
2(4,2)\end{array}$ & $4,4 \pm 3,3$ & $\begin{array}{c}- \\
17(48,6) \\
5(50,0) \\
2(100,0)\end{array}$ & $\begin{array}{c}1(100,0) \\
18(51,4) \\
5(50,0) \\
-\end{array}$ & $0,320^{\mathrm{b}}$ \\
\hline \multicolumn{6}{|l|}{ Tingkat Keparahan } \\
\hline $\begin{array}{l}\text { DF } \\
\text { DHF derajat I }\end{array}$ & $\begin{array}{c}44(91,7) \\
4(8,3)\end{array}$ & - & $\begin{array}{r}21(87,5) \\
3(12,5)\end{array}$ & $\begin{array}{c}23(95,8) \\
1(4,2)\end{array}$ & $0,296^{\mathrm{a}}$ \\
\hline
\end{tabular}


Tabel 3 Frekuensi Lama Rawat Inap antara Kelompok Cairan Kristaloid dan Cairan Koloid

\begin{tabular}{|c|c|c|c|c|}
\hline $\begin{array}{c}\text { Lama Rawat Inap } \\
\text { (hari) }\end{array}$ & $\begin{array}{c}\text { Kelompok } \\
\text { Cairan Kristaloid } \\
(\mathrm{n}=\mathbf{2 4})\end{array}$ & $\begin{array}{c}\text { Kelompok } \\
\text { Cairan Koloid } \\
\quad(n=24)\end{array}$ & $\begin{array}{c}\text { Total } \\
(n=48)\end{array}$ & Nilai p \\
\hline 3 & $3(12,5 \%)$ & $5(20,8 \%)$ & $8(16,7 \%)$ & \\
\hline 4 & $6(25,0 \%)$ & $14(58,4 \%)$ & $20(41,7 \%)$ & \\
\hline 5 & $6(25,0 \%)$ & $5(20,8 \%)$ & $11(22,9 \%)$ & \\
\hline 6 & $7(29,1 \%)$ & - & $7(14,6 \%)$ & $0,002^{a^{*}}$ \\
\hline 7 & $1(4,2 \%)$ & - & $1(2,1 \%)$ & \\
\hline 8 & $1(4,2 \%)$ & - & $1(2,1 \%)$ & \\
\hline Mean $\pm \mathrm{SD}$ & $5,00 \pm 1,2$ & $4,00 \pm 0,659$ & & \\
\hline Total & $24(100,0 \%)$ & $24(100,0 \%)$ & $48(100,0 \%)$ & \\
\hline
\end{tabular}

Keterangan: ${ }^{a}$ independent $t$-test; * ${ }^{\text {signifikan }}$

sesuai dengan penelitian oleh Hukom (2013) yang menunjukkan bahwa proporsi pasien DBD perempuan $(53,2 \%)$ lebih banyak bila dibandingkan laki-laki. ${ }^{11}$ Berdasarkan usia, mayoritas usia pasien berada di rentang 1-5 tahun, yakni sebanyak 35 pasien $(72,9 \%)$. Hasil ini sesuai dengan hasil penelitian oleh Muliansyah (2015) pasien DBD didominasi oleh pasien usia di bawah 15 tahun sebanyak 44 orang $(90 \%) .{ }^{12}$ Penelitian lainnya oleh Saraswathy (2013) di India, jumlah penderita DBD positif terbanyak pada kelompok anak usia 1-5 tahun (57\%), diikuti oleh 6-12 tahun $(29 \%) .{ }^{13}$ Sampai saat ini, kelompok usia tidak berpengaruh secara signifikan, namun berdasarkan hasil penelitian terdahulu, usia $<15$ tahun lebih rentan terserang virus DBD. Hal tersebut kemungkinan disebabkan anak usia dibawah 5 tahun mempunyai risiko 3 kali lebih tinggi tertular virus dengue dibanding anak yang berusia di atas 5 tahun disebabkan rendahnya tingkat imunitas pada umumnya. ${ }^{14}$

Berdasarkan tingkat keparahan penyakit, hasil penelitian ini menunjukkan mayoritas tingkat keparahan responden penelitian berada pada kategori dengue fever (DF) sebanyak 44 pasien $(91,7 \%)$ yang terdiri dari 21 pasien kategori DF pada kelompok cairan kristaloid dan 23 pasien kategori DF pada kelompok cairan koloid, sedangkan kategori dengue hemorrhagic fever (DHF) derajat I sebanyak 4 pasien $(8,3 \%)$ yang terdiri dari 3 pasien kategori DHF derajat I pada kelompok cairan kristaloid dan 1 pasien DHF derajat I pada kelompok cairan koloid. Hasil analisis yang dilakukan dengan menggunakan uji ChiSquare menunjukkan nilai $\mathrm{p}=0,296(\mathrm{p}>0,05)$, yang artinya tidak terdapat perbedaan yang signifikan antara tingkat keparahan DF atau DHF terhadap kelompok cairan kristaloid maupun kelompok cairan koloid.

Berdasarkan hasil penelitian pada Tabel 3, kelompok cairan koloid memiliki rentang lama rawat inap yang lebih singkat yaitu 3 hingga 5 hari dengan mayoritas lama rawat inap 4 hari $(58,4 \%)$, sedangkan kelompok cairan kristaloid memiliki rentang lama rawat inap 3 hingga 8 hari dengan mayoritas lama rawat inap yaitu 5 hari (25\%). Hasil ratarata lama rawat inap pasien kelompok cairan

Tabel 4 Persentase Efektivitas Terapi Cairan Terhadap Lama Rawat Inap

\begin{tabular}{lccc}
\hline \multicolumn{1}{c}{ Jenis Cairan } & $\begin{array}{c}\text { Pasien dengan Lama } \\
\text { Rawat Inap }<\mathbf{5} \text { hari }\end{array}$ & Jumlah Pasien (N=48) & Efektivitas Terapi (\%) \\
\hline Kristaloid & 9 & 24 & 37 \\
Koloid & 19 & 24 & 79 \\
\hline
\end{tabular}


Tabel 5 Analisis Rata-Rata Biaya Total Terapi Demam Berdarah pada Kelompok Kristaloid dan Koloid

\begin{tabular}{|c|c|c|c|}
\hline \multirow[b]{2}{*}{ Variabel } & \multicolumn{2}{|c|}{ Biaya Rata-Rata (Rp) } & \multirow[b]{2}{*}{ Nilai p } \\
\hline & $\begin{array}{c}\text { Kelompok } \\
\text { Cairan Kristaloid }\end{array}$ & $\begin{array}{c}\text { Kelompok } \\
\text { Cairan Koloid }\end{array}$ & \\
\hline Administrasi & 86.667 & 89.333 & \\
\hline Biaya rawat inap & 679.800 & 611.108 & \\
\hline Biaya tindakan medis & 538.813 & 441.542 & \\
\hline Biaya pelayanan medis & 259.617 & 215.058 & $0,801^{\mathrm{a}}$ \\
\hline Biaya obat & 401.009 & 630.253 & \\
\hline Biaya laboratorium & 340.250 & 268.958 & \\
\hline Total biaya medik & 2.306.156 & 2.256 .252 & \\
\hline
\end{tabular}

kristaloid diketahui adalah 5 hari dengan standar deviasi 1,2, sedangkan kelompok cairan koloid lebih singkat yaitu 4 hari dengan standar deviasi 0,6. Hasil penelitian lama rawat inap ini secara statistik menunjukkan perbedaan bermakna antara kedua kelompok dengan nilai $\mathrm{p}=0,002(\mathrm{p}<0,05)$. Nisa et al. (2013) di dalam penelitiannya menyebutkan bahwa secara umum rata-rata lama perawatan DBD anak di RS Roemani Semarang yaitu berkisar $4 \pm 1,504$ hari. $^{15}$

Manajemen terapi demam berdarah tidak memiliki pengobatan khusus, tetapi resusitasi cairan yang cepat dengan pemantauan sering menjadi langkah utama untuk menyelamatkan hidup. ${ }^{16}$ Secara teori, cairan yang digunakan untuk mengatasi kehilangan cairan pada ruang intravaskular meliputi normal salin, ringer laktat ataupun koloid. ${ }^{17}$ Cairan koloid memiliki berat molekul yang lebih besar bila dibandingkan dengan kristaloid sehingga dapat bertahan lebih lama di ruang intravaskular, dan akibatnya dapat memberikan oksigenasi jaringan lebih baik serta hemodinamik terjaga lebih stabil. ${ }^{9}$

Berdasarkan Tabel 4, diketahui efektivitas terapi terhadap lama rawat inap pada pasien yang mendapat cairan koloid lebih besar (79\%) dibandingkan dengan kelompok cairan kristaloid (37\%). Hal tersebut menunjukkan cairan koloid dapat mengurangi lama rawat inap pasien. Hasil analisis independent t-test pada Tabel 5 menunjukkan bahwa tidak ada perbedaan rata-rata total biaya medis yang bermakna secara statistik antara kelompok cairan kristaloid bila dibandingkan kelompok cairan koloid, dengan nilai $\mathrm{p}=0,801(\mathrm{p}<0,05)$.

Pada penelitian ini juga dilakukan analisis perhitungan biaya. Pada Tabel 5, diketahui rata-rata total biaya medis pada kelompok cairan kristaloid yaitu Rp2.306.156/pasien, dan kelompok cairan koloid Rp2.256.252/pasien. Komponen biaya tertinggi pada kelompok koloid yaitu biaya obat sebesar Rp630.253, sedangkan pada kelompok kristaloid biaya obat diketahui lebih rendah yaitu Rp401.009. Besar biaya rawat inap pada kelompok cairan kristaloid, yang juga merupakan komponen biaya tertinggi, adalah Rp. 679.800 . Hal ini sesuai dengan fakta bahwa kelompok cairan kristaloid memiliki waktu lama rawat inap yang lebih lama bila dibandingkan kelompok

Tabel 6 Rasio Rata-Rata Efektivitas Biaya Kelompok Cairan Kristaloid dan Cairan Koloid

\begin{tabular}{lcc}
\hline \multicolumn{1}{c}{ Variabel } & Kelompok Cairan Kristaloid & Kelompok Cairan Koloid \\
\hline Rata-rata total biaya medis (Rp) & 2.306 .156 & 2.256 .252 \\
Efektivitas terapi (\%) & 37 & 79 \\
ACER & 62.328 & 28.56 \\
\hline
\end{tabular}

Keterangan: ACER=Average cost-effectiveness ratio 
cairan koloid.

Hasil perhitungan ACER pada Tabel 6 menunjukkan nilai ACER yang diperoleh pada kelompok kristaloid adalah Rp62.328/ efektivitas, dan Rp28.560/efektivitas pada kelompok koloid. Untuk menentukan apakah diperlukan perhitungan nilai incremental cost-effectiveness ratio (ICER), dilakukan pengisian tabel posisi alternatif pengobatan (Tabel 1) yang mengacu pada Pedoman Penerapan Kajian Farmakoekonomi (2013). Diperoleh hasil bahwa penelitian ini masuk ke dalam posisi dominan (kolom $\mathrm{H}$ ) yang artinya jika intervensi kesehatan menawarkan efektivitas lebih tinggi dengan biaya sama, maka sudah pasti intervensi tersebut terpilih, sehingga tidak perlu dilakukan perhitungan rasio ICER. Berdasarkan Tabel 6, diketahui bahwa nilai ACER kelompok cairan koloid lebih rendah dibandingkan kelompok cairan kristaloid, sehingga terapi cairan koloid lebih cost-effective dibandingkan cairan kristaloid.

Penelitian ini memiliki keterbatasan yaitu subjek DF/DHF dianggap sama dari segi tingkat keparahannya (grade I,II,III,IV). Selain itu, jumlah sampel penelitian ini terbatas, sehingga untuk mendapatkan sampel minimum yang lebih banyak diperlukan peningkatan power penelitian. ${ }^{18}$

\section{Simpulan}

Berdasarkan perhitungan ACER, kelompok cairan koloid memiliki nilai ACER yang lebih rendah dibandingkan kelompok cairan kristaloid sehingga terapi cairan koloid lebih cost-effective dibanding cairan kristaloid.

\section{Ucapan Terima Kasih}

Ucapan terima kasih disampaikan kepada segenap tim peneliti, yakni dokter jaga IGD, apoteker, serta perawat, juga kepada staf Rumah Sakit PKU Muhammadiyah Bantul yang telah membantu dalam pengambilan data penelitian.

\section{Pendanaan}

Penelitian ini tidak didanai oleh sumber hibah manapun.

\section{Konflik Kepentingan}

Seluruh penulis menyatakan tidak terdapat potensi konflik kepentingan dengan penelitian, kepenulisan (authorship), dan atau publikasi artikel ini.

\section{Daftar Pustaka}

1. World Health Organization, Regional Office for South-East Asia. Dengue bulletin. 2016;39.

2. Bhave S, Rajput CS, Bhave S. Clinical profile and outcome of dengue fever and dengue haemorraghic fever in paediatric age group with special reference to WHO guidelines (2012) on fluid management of dengue fever. Int J Adv Res. 2015;3(4); 196-201

3. Suseno, Nasronudin. Pathogenesis of hemorraghic due to dengue virus. Indones J Tropical Infectious Disease. 2015;5(4): 107-11. doi: 10.20473/ijtid.v5i 4.2009

4. Guerdan BR. Dengue fever/dengue hemorrhagic fever. Am J Clin Med. 2010; 7(2):51-3.

5. Sanyaolu A, Okorie C, Badaru O, Adetona K, Ahmed M, Akanbi O, et al. Global epidemiology of dengue hemorrhagic fever: An update. J Hum Virol Retrovirol. 2017;5(6):00179. doi: 10.15406/jhvrv.20 17.05.00179

6. Cavailler P, Tarantola A, Leo YS, Lover AA, Rachline A, Duch M, et al. Early diagnosis of dengue disease severity in a resource-limited Asian country. BMC Infect Dis. 2016;16(1):512. doi: 10.1186/ s12879-016-1849-8 
7. Cucunawangsih, Lugito NPH. Trends of dengue disease epidemiology. Virology. 2017;8:1-6. doi: 10.1177/1178122X1769 5836

8. Hung NT. Fluid management for dengue in children. Paediatr Int Child Health. 2012; 32(1):39-42. doi: 10.1179/2046904712Z. 00000000051

9. World Health Organization. National guidelines for clinical management of dengue fever, India. USA: World Health Organization; 2015.

10. Chen K, Pohan HT, Sinto R. Diagnosis dan terapi cairan pada demam berdarah dengue. Medicinus. 2009;22(1):5-10.

11. Hukom AOE, Warouw SM, Memah M, Mongan AE. Hubungan nilai hematokrit dan jumlah nilai trombosit pada pasien demam berdarah dengue. J e-Biomedik. 2013;1(1):707-11.

12. Saraswathy MP, Sankari K, Gnanavel S, Dinesh S, Priya L. Incidence of dengue hemorrhagic fever in children: A report from Melmaruvathur Tamilnadu India. J Pharm Sci Innov. 2013;2(1):34-6

13. Muliansyah, Baskoro B. Analisa pola sebaran demam berdarah dengue terhadap penggunaan lahan dengan pendekatan spasial di Kabupaten Banggai Provimsi Sulawesi Tengah tahun 2011-2013. J Inform Syst Public Health. 2016;1(1):47-54.

14. Permatasari DY, Rumaningrum G, NovitasariA. Hubungan status gizi, umur dan jenis kelamin dengan derajat infeksi dengue pada anak. J Kedokteran Muhammadiyah Universitas Muhammadiyah Semarang. 2013;2(1):24-8.

15. Nisa WD, Notoatmojo H, Rohmani A. Karakteristik demam berdarah dengue pada anak di Rumah Sakit Roemani Semarang. J Kedokteran Muhammadiyah Universitas Muhammadiyah Semarang. 2013;1(2):93-7

16. Kularatne SAM, Weerakoon KGAD, Munasinghe R, Ralapanawa UK, Pathirage $\mathrm{M}$. Trends of fluid requirement in dengue fever and dengue haemorrhagic fever: A single centre experience in Sri Lanka. BMC Res Notes. 2015;8:130. doi: 10.1186/s131 04-015-1085-0

17. Rajapakse S. Dengue shock. J Emerg Trauma Shock. 2011;4(1):120-7

18. Sastroasmoro S, Ismael S. Dasar-dasar metodologi penelitian klinis, edisi ke-5. Jakarta: Sagung Seto; 2014. 